\title{
Use of agroecological soil monitoring data in designing adaptive landscape farming systems
}

\author{
S.V. Lukin ${ }^{1,2, *}$, and $V . A$. Chernikov ${ }^{3}$ \\ ${ }^{1}$ Belgorod Center for Agrochemical Service, Belgorod, Russian Federation \\ ${ }^{2}$ Belgorod State National Research University, Belgorod, Russian Federation \\ ${ }^{3}$ Russian State Agrarian University - Moscow Timiryazev Agricultural Academy, Moscow, Russia
}

\begin{abstract}
The article analyzes the experience of using agroecological monitoring data in designing adaptive landscape systems of agriculture and soil protection in the Belgorod region. On the basis of data on soil acidity, design and estimate documentation for liming is developed. Materials on the content of soil organic matter are used in the design of measures to form a deficient balance of humus. Information on the availability of arable soils with mobile forms of phosphorus and potassium is necessary for calculating doses of mineral fertilizers. With low availability of mobile forms of sulphur and trace elements, recommendations are being developed for the use of fertilizers containing scarce elements. As a result of the implementation by agricultural producers of projects of adaptive landscape systems of agriculture and soil protection, in 2015-2018, compared to 2010-2014, the use of mineral fertilizers increased by $14.4 \mathrm{~kg} / \mathrm{ha}$, organic - by 3.3 tons $/ \mathrm{ha}$, lime production - by 38.1 thousand ha/year. As a result, arable land productivity increased by 1.01 thousand feed units.
\end{abstract}

\section{Introduction}

Long-term agricultural use of lands often leads to various types of degradation, which fully applies to the potentially most productive soils of Russia - the chernozems of the Central Black Earth Region. They are characterized by the progressive development of erosion processes, dehumification, acidification. Therefore, the rational use of arable soils is one of the key tasks of modern agriculture. For an effective and scientifically grounded solution of this problem, the Governor's Resolution No. 9 "On approval of the Regulations on the project of an adaptive landscape system of agriculture and soil protection" was adopted in the Belgorod region in 2014. With this normative document, land users are obliged to carry out measures for the protection and reproduction of soil fertility in accordance with the requirements set out in this project. Since the main anthropogenic factor in regulating soil fertility and productivity of agrocenoses is the application of fertilizers, a special place in the projects is given to the development of a fertilization system for agricultural crops [1]. Its preparation is based on the actual data of agroecological soil monitoring carried out by the agrochemical service of Russia. To solve specific problems, the geographic information

\footnotetext{
${ }^{*}$ Corresponding author: serg.lukin2010@yandex.ru
} 
system (GIS) "Agroecologist Online" is used, which allows to automatically calculate the doses of fertilizers considering the agroecological state of each working area [2, 3, 4].

The purpose of the research. To analyze and summarize the experience of using agroecological monitoring materials in the development of projects for adaptive landscape systems of agriculture and soil protection.

\section{Materials and Methods}

The work used materials from the last completed cycle (10) of continuous agroecological monitoring of arable soils in the Belgorod region carried out in 2015-2018. During the survey, a combined soil sample was taken from the topsoil from an area of 20 hectares. The soil cover of the region is represented in the forest-steppe zone mainly by typical and leached chernozems, in the steppe zone - by ordinary ones. The Selyaninov hydrothermal coefficient (HTC) varies from 0.9 in the southeast to 1.2 in the west of the region. In soil samples, the content of organic matter was determined by the Tyurin method, mobile forms of phosphorus and potassium - by the Chirikov method, mobile forms of manganese, zinc, copper and cobalt (extractant - ammonium acetate buffer solution with $\mathrm{pH} 4.8$ ), mobile forms of sulfur (extractant is $1 \mathrm{M}$ solution $\mathrm{KCl})$. Soil acidity $\left(\mathrm{pH}_{\mathrm{KCl}}\right)$ was determined according to GOST 26483-85.

\section{Results and Discussion}

When developing projects for adaptive landscape systems of agriculture and soil protection, electronic maps and field passports made in the course of continuous agroecological monitoring are used. The most important factor affecting the efficiency and payback of fertilizers is soil acidity. It is especially important to consider this parameter in crop rotations with sugar beet, which forms high productivity on soils with a close to neutral or neutral reaction of the medium. Therefore, when developing a fertilization system, the soils are firstly grouped according to the degree of acidity, and in the presence of acidic soils, the sequence of their liming is developed. Immediately before liming, design estimates are developed. In 2015-2018 in the Belgorod region, about 300 thousand hectares of acidic soils were limed, as a result of which the share of weakly acidic soils decreased by $3.3 \%$, moderately acidic by $6.8 \%$, to 29.7 and $5.8 \%$, respectively (Fig. 1 ).

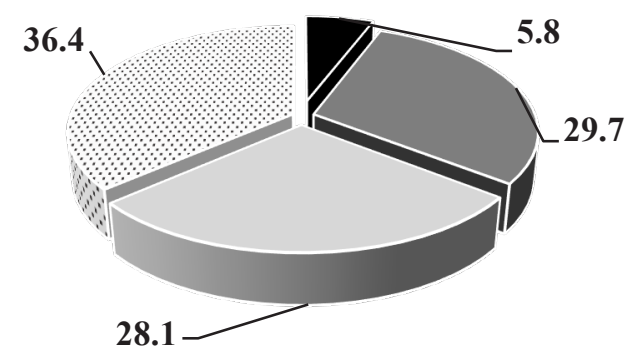

\begin{tabular}{|c|}
\hline - medium acid ( $\mathrm{pH} 4.6-5.0)$ \\
\hline - weakly acid (pH 5.1-5.5) \\
\hline - close to neutral (pH 5.6-6.0) \\
\hline - neutral $(\mathrm{pH}>6.0)$ \\
\hline
\end{tabular}

Fig. 1. Grouping of arable soils in the Belgorod region by $\mathrm{pH}_{\mathrm{KCl}}$ (2015-2018).

When developing a fertilization system, all the resources of organic fertilizers available on farms are considered in the first place. As a rule, they are applied under cultivated crops and in limed fields. The amount of the active substance of the nutrients supplied with organic matter is considered when calculating the doses of mineral fertilizers. In the fields where the application of organic fertilizers is not provided, it is planned to sow green manure crops to stabilize the content of organic matter in the soil [5, 6]. In 2015-2018 in the Belgorod region, 
the average dose of organic fertilizers' introduction amounted to $8.1 \mathrm{t} / \mathrm{ha}$; green manure crops were sown annually on an area of 277.5 thousand hectares (19.4\% of the total sown area), as a result, the weighted average content of organic matter in soils increased by $0.2 \%$ compared with 2010-2014. Most arable soils (70.6\%) are classified as medium-rich in organic matter (Fig. 2)
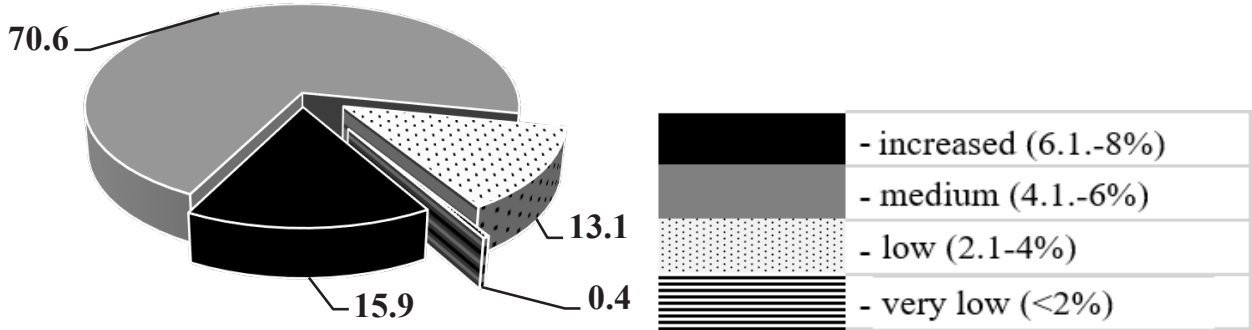

Fig. 2. Grouping of arable soils in the Belgorod region by the provision of organic matter (2015-2018).

The calculation of the nitrogen fertilizers' doses is carried out considering the removal of this element by the planned yield and the type of predecessors (legumes or others). The doses' calculation of phosphorus and potash fertilizers is carried out considering the removal of these elements with the planned yield of agricultural crops and the actual provision of soils with their mobile forms. The less the soil is provided with mobile forms of phosphorus and potassium, the more fertilizers will be required to achieve the planned yield. With a very high supply of soils with mobile forms of phosphorus (more than $200 \mathrm{mg} / \mathrm{kg}$ ) and potassium (more than $180 \mathrm{mg} / \mathrm{kg}$ ), the economic efficiency of these elements' introduction with mineral fertilizers is very low or absent. When calculating the doses of nutrients' introduction with mineral fertilizers, their amount entering the agrocenoses with organic fertilizers is considered. In 2015-2018, the proportion of soils with a very high phosphorus content was $17.6 \%$, and potassium - $33.8 \%$ (Fig. 3, 4). Compared to 2010-2014, the weighted average content of mobile phosphorus and potassium in soils over these years increased by 8 and $25 \mathrm{mg} / \mathrm{kg}$, respectively. Organic fertilizers are the main source of phosphorus and potassium in the region's agrocenoses.
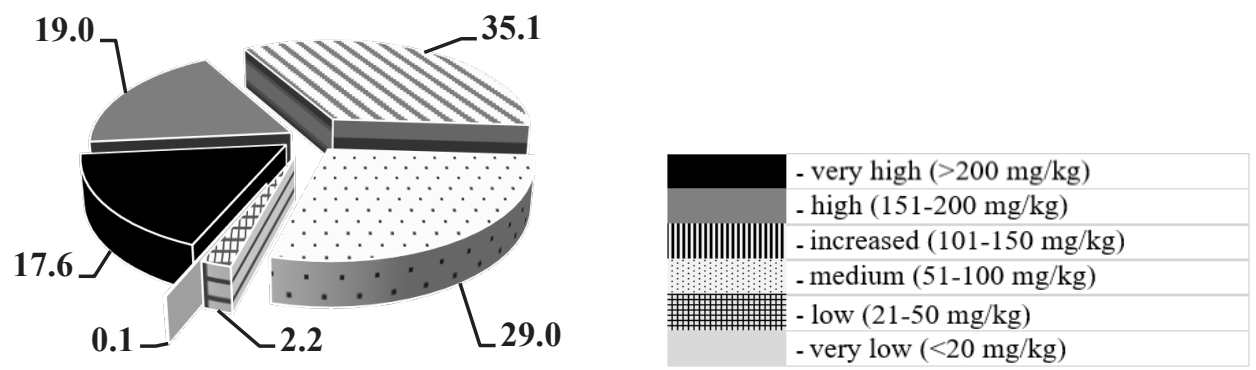

Fig. 3. Grouping of arable soils in the Belgorod region according to the availability of mobile forms of phosphorus (2015-2018). 

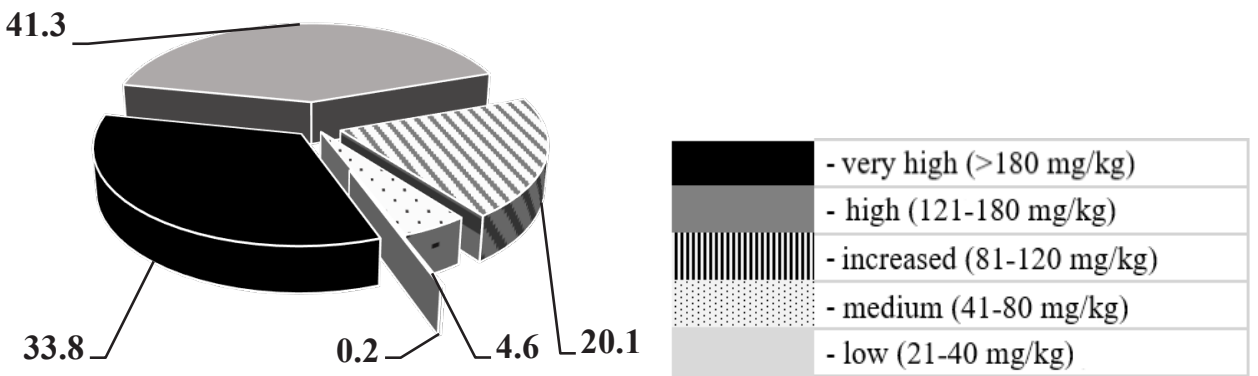

Fig. 4. Grouping of arable soils in the Belgorod region according to the availability of mobile forms of potassium (2015-2018).

In the system of mineral plants' nutrition, an important place is given to the optimization of meso- and micronutrient fertilizers' introduction. According to the monitoring results, the need to use sulfur fertilizers was established on the area of arable soils equal to $90.4 \%$; microfertilizers containing cobalt - on the area of $99.4 \%$, copper 98.2, zinc - 98.7, manganese - 38.6\% (Fig. 5). Low provision of chernozems with these elements is characteristic of the entire Central Chernozem region [7-11]. Out of the sulfur-containing fertilizers, ammonium sulfate is mainly used in the region. The range of micronutrient fertilizers used is quite large, but mainly these are chelated forms of microelements, which are recommended to be used for seed treatment and foliar application.

When conducting agroecological monitoring, a large place is given to the determination of elements of the first toxicity group in soils (cadmium, lead, mercury, arsenic). In the arable soils of the Belgorod region, no cases of exceeding the maximum permissible concentrations of these metals were detected, therefore, no special measures are planned to reduce their translocation into plants [12-14].

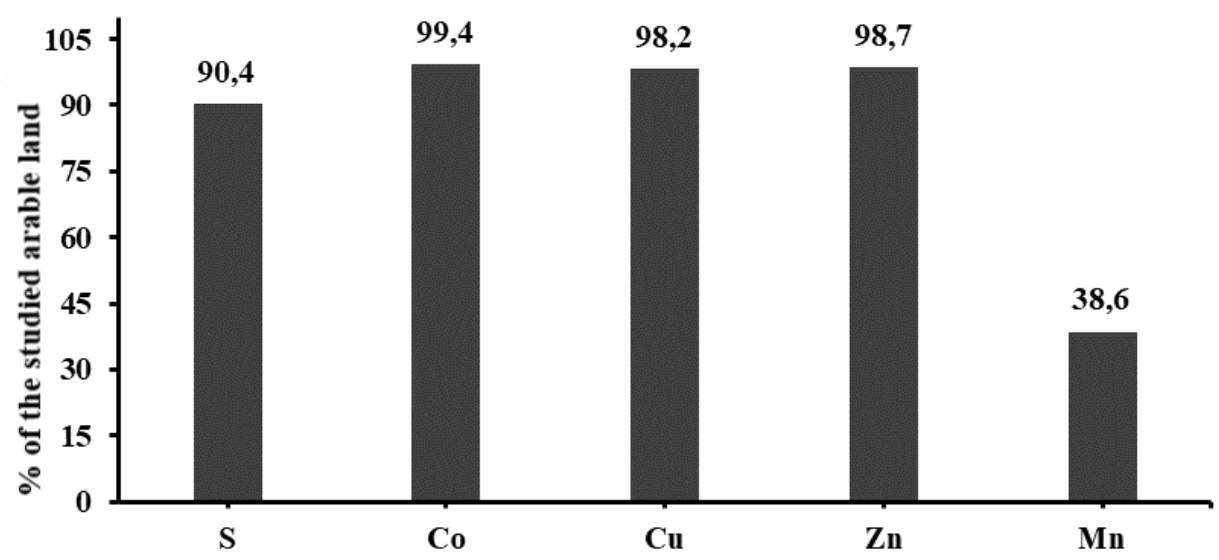

Fig. 5. The share of arable soils in the Belgorod region poorly supplied with mobile forms of sulfur and microelements, $\%$ of the studied area.

In 2015-2018 compared to 2010-2014, as a result of projects' implementation of adaptive landscape systems of agriculture and soil protection by agricultural producers of the Belgorod region, the use of mineral fertilizers increased by $14.4 \mathrm{~kg} / \mathrm{ha}$, organic fertilizers - by $3.3 \mathrm{t} / \mathrm{ha}$, liming volumes - by 38.1 thousand ha/year. As a result, the productivity of arable land increased by an average of 1.01 thousand fodder units. 


\section{Conclusion}

Thus, in the development of a fertilization system for agricultural crops in the projects of adaptive landscape systems of agriculture and soil protection, the materials of agroecological monitoring are fully used. Based on data on soil acidity, design estimates for liming are developed. Materials on the content of soil organic matter are used in the design of measures to form a deficit-free humus balance. Information on the availability of arable soils with mobile forms of phosphorus and potassium is necessary for calculating the doses of mineral fertilizers. With a low supply of soils with mobile forms of sulfur and microelements, recommendations are being developed for the use of fertilizers containing deficient elements.

\section{References}

1. V.I. Kiryushin, Eurasian Soil Science, 52(9), 1137-1145 (2019)

2. I.G. Kostin, Achievements of Science and Technology of AICis, 34(9), 96-105 (2020) DOI: 10.24411/0235-2451-2020-10917.

3. I.G. Kostin, E.S. Malysheva, Bulletin of Kazan State Agrarian University, 2(58), 96-101 (2020) DOI: 10.12737/2073-0462-2020-96-101.

4. E.S. Malysheva, I.G. Kostin, R.M. Khizhnyak, International Agricultural Journal, 64(2), 14-19 (2021) DOI: 10.24412/2587-6740-2021-2-14-19.

5. V.M. Semenov, N.V. Pautova, T.N. Lebedeva, D.P. Khromychina, N.A. Semenova, V.O. Lopes de Gerenvu, Eurasian Soil Science, 52(10), 1183-1194 (2019)

6. A.S. Poddubnyi, Achievements of Science and Technology of AICis, 6, 15-17 (2018)

7. S.V. Lukin, D.V. Zhuikov, Eurasian Soil Science, 54(1), 63-71 (2021) DOI: $10.1134 / \mathrm{S} 1064229321010099$.

8. S.V. Lukin, D.V. Zhuikov, I.G. Kostin, E.A. Prazina, A.A. Zavalin, V.A. Chernikov, EurAsian Journal of BioSciences, 13(2), 877-881 (2019)

9. D.V. Zhuikov, Achievements of Science and Technology of AICis, 11, 32-42 (2020)

10. D.V. Zhuikov, Zemledelie, 5, 9-13 (2020)

11. A.E. Badin, T.P. Logoshina, Achievements of Science and Technology of AICis, 10, 18 21 (2019)

12. S.V. Selyukova, Achievements of Science and Technology of AICis, 8, 85-93 (2020)

13. S.V. Lukin, S.V. Selyukova, Eurasian Soil Science, 51(12), 1547-1553 (2018) DOI: $10.1134 / \mathrm{S} 1064229318120074$.

14. S.V. Lukin, S.V. Selyukova, V.A. Chernikov, N.A. Gaitova, Pollution Research, 39(2), 196-201 (2020) 